\title{
Study Of The Institutional Strengthening Of Water User Farmers Organizations In Effort To Improve The Economic Capability And Welfare Of Farmer
}

\author{
Puteri Ayu Pratiwi, Rosdiana Mata, Rosmiati \\ \{puteriayu.pratiwi@gmail.com, Ody.smart@gmail.com, sabenagroup99@gmail.com\} \\ Departement of Accounting,Politeknik Negeri Kupang,Indonesia
}

\begin{abstract}
The national development through the realization of economic independence by moving strategic sectors of the domestic economy. WUO is a social organization of farmers which especially in water management activities in connection with the interests of carrying out joint farming.The problems were identifying as follows: inadequate institutional management, funding and lack of institutional human resource capacity. The purpose of this study is to provide information on institutional strengthening WUO based on Minister of Agriculture Regulation Number 79 of 2012 and to formulate institutional strengthening strategies WUO. Analysis of the data used in this study is descriptive qualitative and SWOT analysis. The results showed that the institutional strengthening of WUO by an average point of $86.60 \%$ considered as a good category. The results of the SWOT analysis showed in Bena Irrigation Area is (Growth) Aggressive Strategy, is an internal strength strategy to take advantage of external opportunities.
\end{abstract}

Keywords: SWOT, Strengthening Institutions, Water User Farmer Organizations

\section{INTRODUCTION}

Agriculture in Indonesia is a potential sector that contributes positively to the national economy. Agricultural GDP in 2014 grew by $4.18 \%$ and contributed $13.38 \%$ to the total national economy. In 2014, the agriculture sector absorbed around 35.76 million or around $30.2 \%$ of the total workforce. The number of poor people in rural areas who are mostly engaged in the agricultural sector declined at a rate of $-3.69 \%$ / year or decreased from around 19.93 million in 2010 to 17.14 million in 2014.

The implementation of the National Long Term Development Plan for 2005-2025 is divided into several stages of development planning in the periodization of the national medium term development plan of 5 (five) years. Development in the 3rd National Medium-Term Development Plan (2015-2019) is directed to strengthen overall development in various fields by emphasizing the achievement of economic competitiveness based on the excellence of natural resources, the quality of human resources and the ability of science and technology which continue to increase.

Development in the area of food sovereignty and poverty alleviation in rural areas is one of the leading sectors in the nine national development priority agendas set out in the 7 th NAWACITA through the realization of economic independence by mobilizing strategic sectors of the domestic economy. In order to support increasing food sovereignty, the Government of Indonesia's policy directives in stabilizing food security from the irrigated agriculture sector are realized through strategies to increase production capacity, to improve irrigation network services and farmers' economic independence. 
There are five pillars of Indonesia's irrigation modernization, first Pillar: increasing the reliability and supply of irrigation water, which is directed at the issue of water conservation, protection of water sources, water allocation, water distribution, and mitigation against flood risks; second Pillar : improving the irrigation facilities and infrastructure, which are directed towards the issue of infrastructure adaptation in the framework of fulfilling services and providing optimal funding and human resources; third pillar: improvement of the irrigation management system, which is directed at the issue of water user rights, agreements on services, sustainable management of irrigation finance, information management, and strengthening of coordination standards between the parties (stakeholders); the fourth main pillars: strengthening of irrigation management institutions, directed at the issue of One System One Management, water distribution systems in irrigation networks, service-oriented, transparency, and accountability; and fifth pillar: human empowerment of irrigation management actors, directed at the issue of strengthening planning resources, and knowledge of infrastructure[1,2].

Water User Farmer Organizations is a social organization of farmers, which does not act and take shelter in groups or political parties, is an organization engaged in agriculture, especially in water management activities in connection with the interests of carrying out joint farming. Member participation is the main elements in spurring activities and to maintain the unifying WUO which is a social character organization formed by members to achieve certain benefits through participation. Therefore WUO must have certain activities to explain the forms of participation and push ahead about mutual benefits. It is expected that these benefits can be distributed fairly and evenly in accordance with contributions in various activities undertaken [3].

South Middle Timor District is one of rice producers in East Nusa Tenggara Province. There are several irrigation systems spread out in several areas which supposed to support agriculture in the district, both potential and functional irrigation. One of the irrigation areas is Bena Irrigation Area. Irrigation management involves the participation of farmers who belonged to WUO in each of the Irrigation Area locations. But the reality in Bena, WUO in Bena's Irrigation of Timor Tengah Selatan Regency found problems in providing and distributing irrigation water properly, the problems that arose were identified as follows:inadequate institutional management, funding and lack institutional management personnel. This condition not only affects the process and production of agricultural businesses in particular but can also trigger conflicts between irrigation water users. In order to maintain and even improve performance appropriately and in accordance with the time needed, so that water can be provided and distributed to the rice fields, it takes various aspects and indicators that support. Therefore, institutional strengthening of WUO is needed in order to improve the economic capacity and welfare of farmers. Based on this background, the central theme that became the title in this study was" Study of The Institutional Strengthening Of Water User Farmer Organizations In Effort To Improve The Economic Capability And Welfare Of Farmer."

\subsection{Research Problem}

1. How is the institutional strengthening of Water User Farmer Organizations from Regulation of Minister of Agriculture Number 79 Year 2012 point of view?

2. What kinds of institutional strengthening strategy should be undertaken by Water User Farmer Organizations in an Effort to Improve Farmer's Economic Capability and Welfare?

\subsection{Research Objectives}

1. To provide information on institutional strengthening of the Water User Farmer Organizations based on Regulation of the Minister of Agriculture No. 79/2012. 
2. To formulate an institutional strengthening strategy for Water User Farmer Organizations (WUO) as an effort to improve the economic capability and welfare of farmers.

\section{LITERATURE REVIEW}

SWOT analysis was interpret as an evaluation of the overall strengths, weaknesses, opportunities, and threats. SWOT analysis is one of the well-known internal and external environmental analysis instruments of the company. This analysis is based on the assumption that an effective strategy will minimize weaknesses and threats. When applied accurately, this simple assumption has a large impact on the design of a successful strategy [4,5].

The function of a SWOT Analysis is to obtain information from a situation analysis and separate it into internal issues (strengths and weaknesses) and external issues (opportunities and threats). The SWOT analysis will explain whether the information indicates something that will help the company achieve its objectives or give an indication that there are obstacles that must be faced or minimized to meet the desired income. SWOT analysis is the systematic identification of various factors to formulate a company's strategy, this analysis is based on logic that can maximize strengths and opportunities, but it can simultaneously lead to weaknesses and threats. The strategic decision making process is always related to the development of mission, objectives, and strategies, and policies of the company. Thus, strategic planner must analyze the company's strategic factors (strengths, weaknesses, opportunities, and threats) in the current conditions. This is called situation analysis. The most popular model for situation analysis is SWOT analysis. There is a division of strategic factors in the SWOT analysis [6-8] namely:

1. Strength factor

Strength is a resource of skills or other advantages relative to competitors and the market needs served by the company or organization. Strengths are special competencies that provide a comparative advantage for companies in the market. Strength can be contained in financial resources, image, market leadership, buyer relations with suppliers, and other factors. The strength factors that are meant by factors owned by a company or organization among others, special competencies contained in the organization which results in ownership of comparative advantage by business units in the market. It is said so because the business unit has a source of skills, reliable products and so on that makes it stronger than competitors in satisfying the planned market needs that will be served by the business unit itself.

2. Weaknesses

Weaknesses are limitations or deficiencies in resources, skills and capabilities that seriously hinder the effective performance of a company or organization. Facilities, financial resources, management capabilities, marketing skills, brand image can be a source of weakness. Weaknesses factors, if people talk about weaknesses that contained in the board of a company, it is meant the limitations or deficiencies in terms of resources, skills and abilities that become a serious barrier to satisfying the performance of organizational performance.

In practical, various limitations and deficiencies can be seen from the facilities and infrastructure owned, low managerial ability, marketing skills that are not in accordance with market demands, products that are not or less attractive to users or prospective users and the level of profitability which less adequate.

\section{Opportunity factors}

Opportunities are important favorable situations in a corporate or organizational environment. Important trends are one source of opportunity. Identification of previously neglected market segments, changes in competitive or regulatory situations, technological changes, and improved relations with buyers or suppliers can provide opportunities for companies or organizations. Opportunity factors are various favorable environmental situations 
for a business unit. What is meant by various situations include: 1)Important trends that occur among product users;2)Identify a market segment that has not yet received attention;3)Changes in competition conditions;4)Changes in laws and regulations that open up new opportunities for business activities;5)Relationships with intimate buyers;6)Harmonious relationships with suppliers.

4. Threat factors

Threats are important situations that unprofitable in a corporate or organizational environment. Threats are a major nuisance to the current position desired by the organization. The entry of new competitors, slow market growth, increasing bargaining power of important buyers or suppliers, technological changes and new or revised regulations can be a threat to the company's successful. Threats are the opposite of the notion of opportunity, thus it can be said that threats are environmental factors which disadvantage to a business unit. If it could not overcome, the threat will become a wedge for the business unit concerned both for the present and the future. In summary, opportunities in the external environment reflect the possibility that threats are potential obstacles.

\section{RESEARCH METHODOLOGY}

This type of research used in this study is a qualitative descriptive study that is research that gives a careful description of an individual or group about the circumstances and symptoms that occur. Qualitative research is a researcher who intends to understand the phenomenon of what is experienced by the research subject holistically and by means of description in the form of words and language, in a special natural context and by utilizing various natural methods [9].

\subsection{Research Locations and Objects}

The location of the study was conducted in South Middle Timor District, Bena Irrigation Area, Linamnutu Village. While the object of research in this study is the SWOT strategy analysis, namely internal factors, namely Strengths and Weaknesses, external factors, namely Opportunities and Threats.

\subsection{Population and Samples}

The target population in this study consisted of the Water User Farmer Organizations in Bena Irrigation Area, namely WUO Oetaman II, WUO Oetaman I and WUO Oetetus. The sample is part of the number and characteristics possessed by the population.

This research used purposive sampling method. Purposive Sampling is a sampling technique with certain considerations by determining the target population element that is estimated to be the most suitable for collecting data[10,11] Respondents were chosen deliberately from 76 farmers.

\subsection{Data Analysis Techniques}

Data analysis technique used in this research is descriptive qualitative, where this technique analyzes research data to solve existing problems $[10,11]$ by taking the following steps:

\section{Descriptive analysis}

To answer the first objective, a descriptive analysis was used to find out the average of the five WUO institutional strengthening based on the Regulation of the Minister of Agriculture No. $79 / 2012$ with the following steps:

1. Verify the data that has been filled in by the respondent.

2. Calculate the scoring of each statement.

3. Calculating relevant respondent 
4. Calculating the score of Respondent Achievement Level (RAL) in each answer category using the formula $[12,13]$ :

$\mathrm{RAL}=\frac{R S}{n} \times 100$

Explanation:

RAL= Respondent Achievement Level

$\mathrm{RS}=$ average of the answer score

$\mathrm{n}=$ the value of the answer score

\section{SWOT Analysis}

SWOT analysis used to formulate an alternative strategy for strengthening the water user farmer association by identifying external factors such as opportunities and threats and internal factors in the form of strengths and weaknesses. In this study, the researcher used an external strategy factor matrix and an internal strategy matrix, the next step was to use the data or information to formulate a strategy.

\section{FINDING AND DISCUSSION}

In legal basis form of Minister of Agriculture Regulation No. 79/2012, the Guidelines for the Guidance and Empowerment of WUO stated that empowerment was carried out to strengthen WUO institutions to become independent so that they could participate actively in irrigation development and management activities, especially participatory tertiary networks. Based on a review of the five aspects obtained the results presented in Table 4.5 are as follows:

Table 4.5 Results of Institutional Strengthening of WUO

\begin{tabular}{|l|c|c|c|}
\hline \multicolumn{1}{|c|}{ Indicators } & Average & RAL ( \% ) & Criteria \\
\hline Organizational aspects & 4,321 & 86,41 & Good \\
\hline Technical aspects of Agricultural & 4,263 & 85,26 & Good \\
\hline Technical aspects of Irrigation & 4,363 & 87,26 & Good \\
\hline Financial aspects & 4,364 & 87,28 & Good \\
\hline Business sector aspects & 4,338 & 86,75 & Good \\
\hline \multicolumn{1}{|c|}{ Average } & $\mathbf{4 , 3 3 0}$ & $\mathbf{8 6 , 6 0}$ & Good \\
\hline
\end{tabular}

Source : Processed primary data,2019

Based on the conditions in Table 4.5 it could be described generally that the institutional strengthening of WUO based on Minister of Agriculture Regulation No. 79/2012 in the Bena's Irrigation Area was in the Good category with an average respondent achievement rate of $86.60 \%$.

\subsection{Strategies of Institutional Strengthening of WUO}

Table 4.6 Identification Internal Factors Analysis Summary

\begin{tabular}{|c|l|c|c|c|}
\hline No & \multicolumn{1}{|c|}{ Strengths } & Point & Rating & Score \\
\hline 1. & $\begin{array}{l}\text { WUO already had a legal entity, complete organizational } \\
\text { structure. }\end{array}$ & 0,208 & 4 & 0,832 \\
\hline 2. & Orderly in financial administration management and fees & 0,224 & 4 & 0,896 \\
\hline 3. & $\begin{array}{l}\text { Decision making was completed by consultation and cultural } \\
\text { customs }\end{array}$ & 0,176 & 3 & 0,528 \\
\hline
\end{tabular}




\begin{tabular}{|c|l|c|c|c|}
\hline 4. & $\begin{array}{l}\text { Participation of WUO management and members in institutional } \\
\text { meetings /activities. }\end{array}$ & 0,192 & 3 & 0,576 \\
\hline 5. & $\begin{array}{l}\text { Awareness of the farmers responsible for irrigation network } \\
\text { techniques }\end{array}$ & 0,200 & 4 & 0,800 \\
\hline & Total strengths Weaknesses & 1,000 & \multicolumn{2}{|c|}{3,632} \\
\hline & \multicolumn{1}{|c|}{ Wres } & 0,698 \\
\hline 1. & $\begin{array}{l}\text { Water fulfillment distribution was not evenly distributed/not } \\
\text { enough / not fair }\end{array}$ & 0,233 & 3 & 0,698 \\
\hline 2. & $\begin{array}{l}\text { The condition of the Regulatory Building and secondary/ } \\
\text { tertiary canal were less than optimal/ declined }\end{array}$ & 0,233 & 3 \\
\hline 3. & $\begin{array}{l}\text { Lack knowledge of farmers about the procedures of agricultural } \\
\text { irrigation networks }\end{array}$ & 0,171 & 2 & 0,341 \\
\hline 4. & Non-compliance with organizational rules & 0,155 & 2 & 0,310 \\
\hline 5. & Conventional Post-harvest marketing & 0,209 & 2 & 0,419 \\
\hline & Total Weaknesses & 1,000 & & 2,465 \\
\hline
\end{tabular}

Source : Processed primary data,2019

Based on table 4.6 showed the total strength score of 3,632 while the total weakness' score of 2,465 .

Table 4.7 Identification External Factors Analysis Summary

\begin{tabular}{|c|l|c|c|c|}
\hline No & \multicolumn{1}{|c|}{ Opportunities } & Point & Rating & Score \\
\hline 1. & Plant high economic plants (increase crop productivity) & 0,160 & 3 & 0,480 \\
\hline 2. & New Agricultural Technology & 0,240 & 4 & 0,960 \\
\hline 3. & Collaboration with Government and Private partners & 0,192 & 4 & 0,768 \\
\hline 4. & $\begin{array}{l}\text { Maintenance Operationalization and Rehabilitation } \\
\text { Funding }\end{array}$ & 0,192 & 4 & 0,768 \\
\hline 5. & Increasing the capacity of farmers and farmer institutions & 0,216 & 3 & 0,648 \\
\hline & Total Opportunity Threats & 1,000 & & 3,624 \\
\hline 1. & Natural Disasters (dry season prolonged) & & & 0,366 \\
\hline 2. & $\begin{array}{l}\text { The selling price of agricultural products decreased in the } \\
\text { main harvest }\end{array}$ & 0,229 & 3 & 0,687 \\
\hline 3. & Operational and Maintenance Funds are increasing & 0,229 & 1 & 0,229 \\
\hline 4. & Primary network damaged & 0,206 & 3 & 0,618 \\
\hline 5. & Livelihoods that unsteady & 0,153 & 1 & 0,153 \\
\hline & Total Threat & 1,000 & & 2,053 \\
\hline
\end{tabular}

Source : Processed primary data,2019

Based on table 4.7 showed the total opportunity score of 3,624 while the total threat score of 2,053 . 


\subsection{SWOT Analysis}

Strength - Opportunity (SO),strategy formulation was an internal strength strategy to take advantage of external opportunities. These strategies are: 1) Improving the quality of management and the quantity of financial sources (contributions, donations and non-binding assistance and legitimate efforts set by the organization) to support the application of new agricultural / agribusiness technologies in terms of superior seeds, fertilizers and tools modern agriculture so as to produce superior agricultural output.

WUO Institution serves as a forum for farmers engagement to exchange ideas, brainstorm and make decisions to solve problems faced by farmers; provide services to farmers for fair and equitable distribution and distribution of irrigation; carry out operations and maintenance, development of irrigation and tertiary networks; regulate members' payments in the form of money, crops, and maintenance of tertiary networks and organizational development efforts. WUO financial resources in the form of membership fees become mandatory for the sustainability of WUO. A quantity increased of fees can support developing horticultural agribusiness technology. Horticultural commodities, namely the vegetables and fruit group, were unique to other agricultural commodities. One of the characteristics is high value and very promising, so it is very competitive to be cultivated. This high value could be a new business area to support the farmers' economy besides rice planting.

The second alternative Strength Opportunity (S-O) strategy improved the clarity of WUO's legal entity status which supported by a complete organizational structure to support the development of farmer partnerships with various market institutions both locally and between regions. The administrators of WUO Oetaman II, WUO Oetaman I and WUO Oetetus registered the Articles of Association with the local Notary Public to obtain legal status. Due to a clear legal status will provide organizational guarantee and protection in expanding partnerships with other parties who wanted to cooperate with organizations both in social and economic terms.

\section{CONCLUSIONS}

Based on the discussion above, it can be summarized WUO Bena Irrigation Region as follows:

1. The results of the analysis of institutional strengthening of the WUO in terms Minister of Agriculture Regulation Number 79/2012 in Bena Irrigation Region is average total RAL value was $86.60 \%$ with a good category.

2. The result of the SWOT analysis matrix showed that the priority strategy is an aggressive Strategy (SO): 1) improving the quality of management and quantity financial sources (contributions, donations and non-binding assistance and legitimate efforts organized by the organization) to support the application of new agricultural / agribusiness technologies in terms of superior seeds, fertilizers and modern agricultural equipment so as to produce superior agricultural products; 2) Increasing the clarity of the legal status of the WUO organization which supported by a complete organizational structure to help the development of farmers' partnerships with various market institutions both locally or in between regions.

\section{ACKNOWLEDGMENTS}

Acknowledgments are conveyed to the Director of Politeknik Negeri Kupang, Head of the Research and Community Service Center of Politeknik Negeri Kupang, Chair of the Accounting Department. Gratitude for the Chairperson and all members of WUO Oetaman II, WUO Oetaman I and WUO Oetetus in Linamnutu Village. 


\section{REFERENCES}

[1] Kementerian Pertanian Republik Indonesia.:Peraturan Menteri Pertanian Nomor 79 Tahun 2012 Tentang Pedoman Pembinaan dan Pemberdayaan Perkumpulan Petani Pemakai Air,Indonesia (2012)

[2] Anthoni, R,Rachmina,D, dan Andati ,T.:Strategi Penguatan Sistem Pengendalian Intern Dalam Penatausahaan Barang Milik Daerah Kabupaten Bogor.Jurnal Manajemen Pembangunan Daerah.8(2): 1 (2016)

[3] Idran.: Studi Strategi Peningkatan Kinerja Gabungan Perkumpulan Petani Pemakai Air (GP3A) Dalam Mengelola Jaringan Irigasi Pada Daerah Irigasi Tindaki Kabupaten Parigi Moutong.e-Jurnal Katalogis, Volume 3 Nomor 9.September hlm 31-41(2015)

[4] Kotler,Keller.: Marketing Manajemen Edisi 14.Global Edition.Pearson Prentice Hall,(2012).

[5] Siagian,Sondang.:Manajemen Stratejik.Bumi Aksara,Jakarta (2012)

[6] David,Fred R.: Manajemen Strategis Konsep.Edisi ke 12.Salemba Empat,Jakarta (2017)

[7] Rangkuti,Freddy.:Analisis SWOT Teknik Membedah Kasus Bisnis.PT. Gramedia Pustaka utama,Jakarta (2015).

[8] Slamet, Rokhmad.:Seminar Akademik Program BBA Jakarta Institute of Management Studies.PT Gramedia Pustaka Utama,Jakarta (2012)

[9] Moleong,Lexy J.: Metode Penelitian Kualitatif Edisi Revisi.PT Remaja Rosdakarya,Bandung (2013)

[10] Sugiyono.:Metode Penelitian Kuantitatif Kualitatif dan R\&D.Alfabeta,Bandung(2018)

[11] Creswell, John W.:A Concise Introduction To Mixed Methods Research.Sage Publications Inc.California(2014)

[12] Arikunto,S.: Prosedur Penelitian: Suatu Pendekatan Praktik,Rineka Cipta,Jakarta(2013)

[13] Riduwan.:Dasar-dasar Statistika.Alfabeta,Bandung(2012). 